\title{
Runoff generating processes in adjacent tussock grassland and pine plantation catchments as indicated by mean transit time estimation using tritium
}

\author{
M. K. Stewart ${ }^{1}$ and B. D. Fahey ${ }^{2}$ \\ ${ }^{1}$ Aquifer Dynamics \& GNS Science, P.O. Box 30 368, Lower Hutt 5040, New Zealand \\ ${ }^{2}$ Landcare Research, P.O. Box 40, Lincoln 7640, New Zealand \\ Received: 1 February 2010 - Published in Hydrol. Earth Syst. Sci. Discuss.: 10 February 2010 \\ Revised: 13 May 2010 - Accepted: 4 June 2010 - Published: 24 June 2010
}

\begin{abstract}
The east Otago uplands of New Zealand's South Island have long been studied because of the environmental consequences of converting native tussock grasslands to other land covers, notably forestry and pasture for stock grazing. Early studies showed that afforestation substantially reduced annual water yield, stream peak flows, and 7-day low flows, mainly as a consequence of increased interception. Tritium measurements have indicated that surprisingly old water is present in catchments $\mathrm{GH} 1$ and $\mathrm{GH} 2$, and the small headwater wetland and catchment (GH5), and contributes strongly to baseflow. The data have been simulated assuming the presence of two types of water in the baseflow, young water from shallow aquifers connecting hillside regolith with the stream, and old water from deep bedrock aquifers, respectively. The mean transit time of the young water is approximately one month, while that of the old water is $25-$ 26 years as revealed by the presence of tritium originating from the bomb-peak in NZ rainfall in late 1960s and early 1970s. Such a long transit time indicates slow release from groundwater reservoirs within the bedrock, which constitute by far the larger of the water stores. Comparison of the results from catchments GH1 (tussock) and GH2 (pine forest) suggests that about equal quantities of water $(85 \mathrm{~mm} / \mathrm{a})$ are contributed from the deep aquifers in the two catchments, although runoff from the shallow aquifers has been strongly reduced by afforestation in $\mathrm{GH} 2$. This study has revealed the presence of a long transit time component of water in runoff in a catchment with crystalline metamorphic bedrock.
\end{abstract}

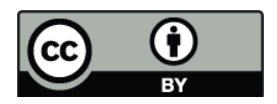

Correspondence to: M. K. Stewart (m.stewart@gns.cri.nz)

\section{Introduction}

Understanding streamwater sources and residence times is important for managing the quality and quantity of water produced by catchments, especially if land use is changing. This paper describes the application of dating techniques to the identification of water sources in the Glendhu Experimental Catchments.

The east Otago uplands of New Zealand's South Island have long been the focus of attention because of the environmental consequences of converting native tussock grasslands to other land covers, notably forestry and pasture for stock grazing. As a response to some of these concerns, a paired catchment study was established at Glendhu in 1980 in the upper Waipori river basin $60 \mathrm{~km}$ west of the city of Dunedin to assess the hydrological effects of the afforestation of tussock grassland. After a 3-year calibration period (1980-1982, Pearce et al., 1984), one catchment (GH2, 310 ha) was planted in Monterey pine (Pinus radiata) and the other (GH1, 218 ha) left in native tussock grassland as a control. Subsequent analyses have shown that afforestation has substantially reduced annual water yield, stream peak flows, and 7-day low flows (Fahey and Jackson, 1997) mainly as a consequence of increased interception, but also from increased evapotranspiration.

Previous workers have applied a variety of methods to elucidate the mechanisms responsible for both stormflow and baseflow generation in the control catchment (GH1). Bonell et al. (1990) examined the sources of water for selected storms, based on analyses of the naturally occurring isotope deuterium $\left({ }^{2} \mathrm{H}\right)$ and chloride. They found that runoff from storms in the small to moderate size range were dominated by pre-event water (with a composition identical to that prior to the storm event), while larger storms contained both event and pre-event water. Runoff in the later phase of

Published by Copernicus Publications on behalf of the European Geosciences Union. 
baseflow recession was dominated by pre-event water. They suggested that numerous small wetlands in the headwaters of the larger catchments acted as temporary storage areas supplying pre-event water. Miller (1994), however, concluded that these features may not be important sources of baseflow, but merely serve to link the surrounding hillslopes with the streams that drain them. Fahey et al. (1998) and Bowden et al. (2001) found that storm runoff occurs primarily as interflow, and that baseflow can be sustained for long periods from soil moisture stored in the deep loess horizons blanketing the surrounding hillslopes, but only for a few days from the water in the bog itself.

The present study uses tritium to examine the transit time of water flowing from the tussock and forested catchments (GH1 and GH2), and one of the small headwater catchments containing a wetland (GH5). In particular, the effects of the different land treatments in $\mathrm{GH} 1$ and $\mathrm{GH} 2$ are investigated.

\section{Background}

\subsection{Glendhu catchments}

The catchments display rolling-to-steep topography, and range in elevation from 460 to $650 \mathrm{~m}$ a.s.l. (Fig. 1). Bedrock is moderately-to-strongly weathered schist, with the weathered material filling in pre-existing gullies and depressions. Much of the bedrock-colluvial surface is overlain by a loess mantle of variable thickness ( 0.5 to $3 \mathrm{~m}$ ). Well-to-poorly drained silt loams are found on the broad interfluves and steep side slopes, and poorly drained peaty soils in the valley bottoms. Amphitheatre-like sub-catchments (e.g. GH5) are common features in the headwaters of both GH1 and GH2. They frequently exhibit central wetlands that extend downstream as riparian bogs. Snow tussock (Chionochloa rigida) is the dominant vegetation cover in the control catchment (GH1); Monterey pine (pinus radiata) extends over $67 \%$ of GH2. Headwater wetlands have a mixed cover of sphagnum moss, tussock, and wire grass (Empodisma minus). The mean annual temperature at GH5 (elevation $625 \mathrm{~m}$ a.s.l.) is $7.6^{\circ} \mathrm{C}$, and the mean annual rainfall is $1350 \mathrm{~mm} / \mathrm{a}$. Annual runoff is measured at all weirs to an accuracy of $\pm 5 \%$ (Pearce et al., 1984).

\subsection{Master recession curve}

Figure 2 shows the master recession curve, not involving snowmelt or additional rainfall, derived by Pearce et al. (1984) from the longest recessions observed during a 3year study period in GH1 and GH2 (before afforestation). This recession curve is typical of high to medium runoff events. The plot shows that there is a marked change of slope between the early and late parts of the recessions (at a flow of about $2.6 \mathrm{~mm} /$ day, where $1 \mathrm{~mm} /$ day equals $0.12 \mathrm{~L} / \mathrm{s} / \mathrm{ha}$ ). Quickflow, as defined by Hewlett and Hibbert (1967), com-

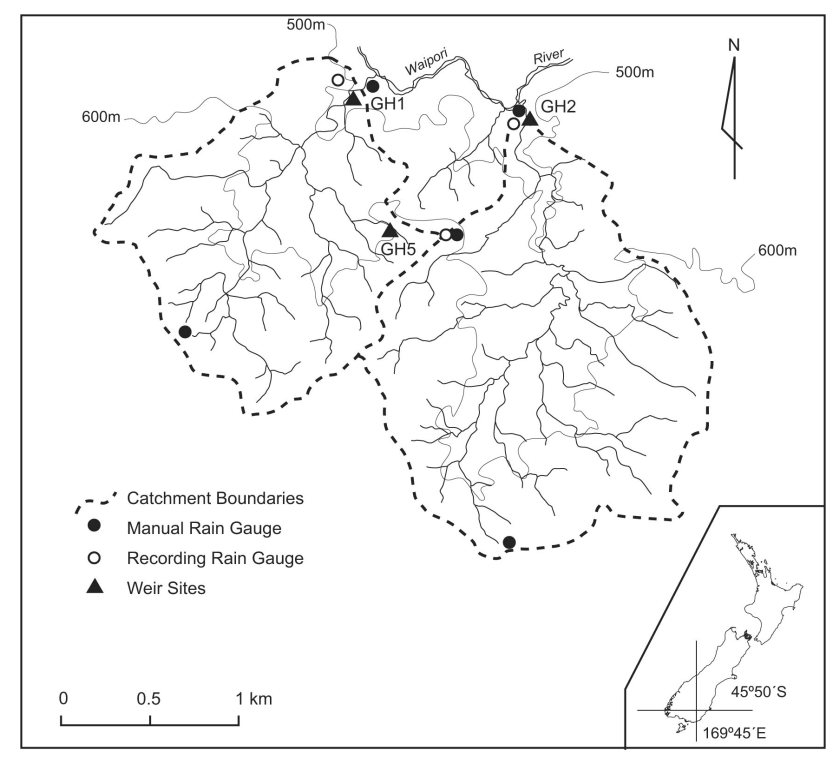

Fig. 1. Map of Glendhu catchments (GH1, GH2 and GH5).

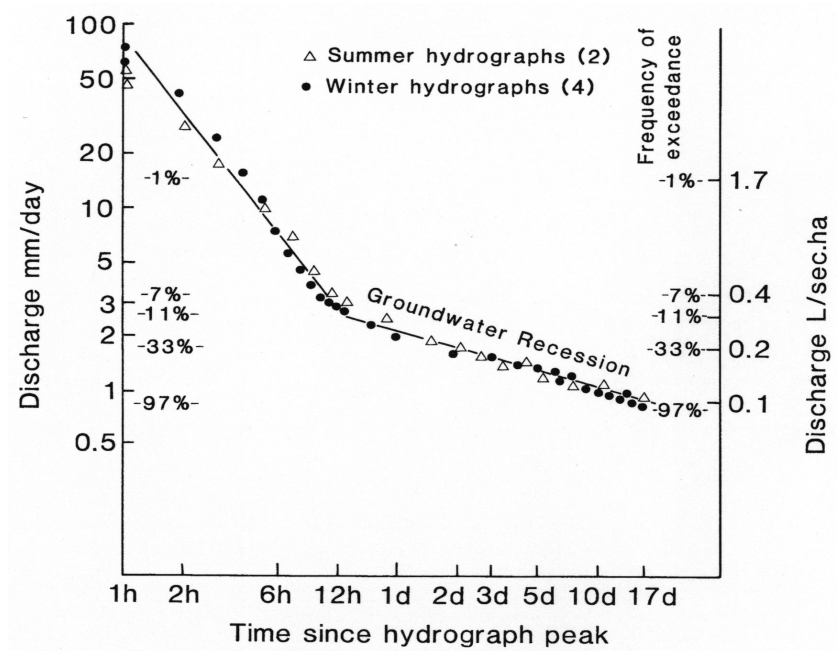

Fig. 2. Master recession curve for Glendhu catchments (from Pearce et al., 1984).

prises $30 \%$ of the annual hydrograph and ceases shortly after the change in recession rate in most storm hydrographs (Pearce et al., 1984).

\subsection{Deuterium results}

Hydrograph separation of event and pre-event water was carried out using deuterium and chloride to investigate the runoff mechanisms operating in $\mathrm{GH} 1$ and $\mathrm{GH} 2$, and the causes of the transition point in the master recession curve (Bonell et al., 1990). Results showed that for quickflow volumes greater than $10 \mathrm{~mm}$, the first part of the storm 
hydrograph could be attributed to two sources, pre-event water from a shallow unconfined groundwater aquifer, and event water from saturation overland flow. The pre-event water responded more rapidly to rainfall than the event water. For quickflow volumes less than $10 \mathrm{~mm}$, only pre-event water from groundwater contributed. The second part of the hydrograph consisted only of pre-event water, from a very wellmixed shallow unconfined groundwater body.

\subsection{Hydrological balances at GH1 and GH2}

Pearce et al. (1984) showed that GH1 and GH2 (before the latter was forested), had very similar runoff ratios. Long term precipitation and runoff at GH1 weir average $1350 \mathrm{~mm} / \mathrm{a}$ and $743 \mathrm{~mm} / \mathrm{a}$, respectively (Fahey and Jackson, 1997). Actual evapotranspiration of $622 \mathrm{~mm} / \mathrm{a}$ was measured for tussock grassland in the period April 1985 to March 1986 at a nearby site in catchment GH1 (570 m a.s.l.) by Campbell and Murray (1990) using a weighing lysimeter. The PriestleyTaylor estimate of PET was $643 \mathrm{~mm} / \mathrm{a}$ for the period, and $599 \mathrm{~mm} / \mathrm{a}$ for 1996, so ET for GH1 is taken as $600 \mathrm{~mm} / \mathrm{a}$. The GH1 hydrological balance is: Precipitation $(1350 \mathrm{~mm} / \mathrm{a})$ - ET $(600 \mathrm{~mm} / \mathrm{a})=$ Runoff $(743 \mathrm{~mm} / \mathrm{a})$, and loss around the weir is clearly negligible (Pearce et al., 1984). Comparison of runoff from GH1 and GH2 (after the latter had been forested for 7 years), showed that there was a decrease of $260 \mathrm{~mm} / \mathrm{a}$ in GH2 runoff due to afforestation (Fahey and Jackson, 1997). Consequently, the GH2 balance is: Precipitation $(1350 \mathrm{~mm} / \mathrm{a})-\mathrm{ET}(860 \mathrm{~mm} / \mathrm{a})=\operatorname{Runoff}(483 \mathrm{~mm} / \mathrm{a})$. The increase in ET for GH2 is attributed to increased interception (with evaporative loss) and transpiration. Runoff at GH5 weir was found to be $404 \mathrm{~mm} / \mathrm{a}$, suggesting that there was loss of water around the weir (confirmed by visual inspection).

\section{Methods}

\subsection{Tritium, CFC and other measurements}

Samples were collected from the small wetland $(0.39$ ha) in GH5 (3.64 ha), from different sites along the stream originating in the wetland, and from the outlets of catchments GH1 (218 ha) and GH2 (310 ha), in December 2001, February 2005, and February 2009. The measurements were made at the Water Dating Laboratory of GNS Science.

Tritium samples were collected in $1.1 \mathrm{~L}$ glass bottles, which were allowed to overflow before being tightly capped, in order to prevent contact with the atmosphere. The samples were electolytically enriched in tritium by a factor of 70 , and counted in an ultra low-background Quantalus liquid scintillation counter (Morgenstern and Taylor, 2009; Hulston et al., 1981). The results are based on the new radioactive halflife of tritium of 12.32 years, and new calibration of standard water SRM4926C (1.100462 $\pm 0.366 \%$ at 3 September 1998, Morgenstern and Taylor, 2009).

Tritium is produced naturally in the atmosphere by cosmic rays, and large amounts were released into the atmosphere by nuclear weapons tests in the early 1960s, giving rain and surface water a relatively high tritium concentration compared to the natural level. The bomb-peak is now much smaller, because of radioactive decay and dispersion, or has completely passed through shorter residence time hydrological systems, but is still the most direct way of determining water ages using tritium. Cosmic ray tritium can also be used for dating groundwater and streamflow, if sufficiently precise tritium measurements are available (McGlynn et al., 2003; Morgenstern and Taylor, 2009; Stewart et al., 2010).

CFC samples were collected air-free in $2.5 \mathrm{~L}$ glass bottles according to methods developed by Busenberg and Plummer (1992) and van der Raaij (2003). The bottles were rinsed in the water to be collected, then filled smoothly from the bottom and allowed to overflow. Care was taken to ensure that there were no small bubbles adhering to the inner sides of the bottle. After overflowing for some time, the tube was slowly removed, leaving a convex meniscus on the top of the bottle. The cap was filled with water, then placed over the meniscus and firmly secured. A shaped nylon liner within the cap expelled any surplus water as the cap was being tightened. Then the bottle was tipped upside down and closely observed to see if any bubbles rose up through the water in the bottle. If any did, the sample was discarded and a new sample was collected. Samples were stored at constant temperature.

Measurements of the dissolved CFC concentrations in the water were made by gas chromatography using a purge and trap method, and EC detector (van der Raaij, 2003). Measurement and use of CFC concentrations for dating groundwater is described by Plummer and Busenberg (1999). Dissolved argon and nitrogen concentrations were also analysed by gas chromatography for the February 2005 samples (van der Raaij, 2003). These were used to determine the excess air concentrations and recharge temperatures of the samples (Plummer and Busenberg, 1999).

$\mathrm{SiO}_{2}$ was measured on the samples collected on 22 February 2005 and 26 February 2009, using inductively coupled plasma optical emission at the GNS Science Water Lab, Wairakei. Silica concentrations are normally low in rainfall, but become higher in water infiltrating the ground because of dissolution or interaction with silicate minerals underground. In general, the longer the residence time of the water in the ground, the greater the silica concentration. Silica concentrations can therefore be used to distinguish rainfall, soil water or short residence time shallow groundwater from longer residence time deeper groundwater.

Deuterium and oxygen-18 were measured on samples from the later sampling trips, using equilibration of the water with $\mathrm{H}_{2}$ and $\mathrm{CO}_{2}$ gases, respectively. The concentration of 
${ }^{18} \mathrm{O}$ in water samples is expressed in the delta $(\delta)$ notation as per mil (\%o) difference between the ${ }^{18} \mathrm{O} /{ }^{16} \mathrm{O}$ ratio of the sample and that of the international standard VSMOW (Vienna standard mean ocean water):

$\delta^{18} \mathrm{O}=\left[\frac{{ }^{18} \mathrm{O} /{ }^{16} \mathrm{O}_{\text {sample }}}{{ }^{18} \mathrm{O} /{ }^{16} \mathrm{O}_{\text {VSMOW }}}-1\right] \times 1000$

The measurement error is $\pm 0.10 \%$ o (standard error based on analysis of duplicate samples).

\subsection{Transit time determination}

Transport of water along the various flowpaths through catchments results in water in the outflow having a range of transit times, i.e. the water does not have a discrete age, but has a distribution of ages. This distribution is described by a flow model, which reflects the average conditions in the catchment.

Inputs to the catchment (e.g. tritium in the recharge water) are modified by passing through the hydrological system (as represented by the flow model) before appearing in the output. The convolution integral and an appropriate flow model are used to relate the tracer input and output. The convolution integral is given by

$C_{\text {out }}(t)=\int_{0}^{\infty} C_{\text {in }}(t-\tau) h(\tau) \exp (-\lambda \tau) d \tau$

where $\mathrm{C}_{\mathrm{in}}$ and $\mathrm{C}_{\text {out }}$ are the input and output concentrations. $\mathrm{t}$ is calendar time and the integration is carried out over the transit times $\tau . \mathrm{h}(\tau)$ is the flow model or response function of the hydrological system. $\lambda\left(=\ln 2 / T_{1}\right)$ is the tritium decay constant. $T_{1 / 2}$ is the half-life of tritium (12.32 years).

Two flow models are commonly used in environmental tracer studies. The exponential-piston flow model (EPM) combines a section with exponential transit times followed by a piston flow section to give a model with parameters of mean transit time $\left(\tau_{\mathrm{m}}\right)$ and exponential fraction (f) (parameters slightly modified from Maloszewski and Zuber, 1982). The response function is given by

$h(\tau)=0$ for $\tau<\tau_{m}(1-f)$

$h(\tau)=\left(f \tau_{m}\right)^{-1} \cdot \exp \left[-\left(\tau / f \tau_{m}\right)+(1 / f)-1\right]$ for $\tau \geq \tau_{m}(1-f)$

where $f$ is the ratio of the exponential to the total volumes, and $\tau_{m}(1-\mathrm{f})$ the time required for water to flow through the piston flow section.

The dispersion model (DM) assumes a tracer transport which is controlled by advection and dispersion processes (Maloszewski and Zuber, 1982)

$h(\tau)=\frac{1}{\tau \sqrt{4 \pi \mathrm{DP}\left(\tau / \tau_{m}\right)}} \exp \left[-\frac{\left(1-\tau / \tau_{m}\right)^{2}}{4 \mathrm{DP}\left(\tau / \tau_{m}\right)}\right]$
The model parameters are the mean transit time $\left(\tau_{\mathrm{m}}\right)$ and dispersion parameter (DP). Although this equation was derived as a solution to the dispersion equation, implying transport and dispersion along a single flowpath, the fact that DP is a fitted parameter means that it effectively includes transit time variance due to space variance from the recharge distribution at the surface, and any diffusive exchange of tracer with stagnant water in the aquifer, as well as the dispersive-convective transport in the aquifer. Hence, the expression has wider application than just aquifer dispersion.

Models can be combined to represent more complicated systems, as illustrated by the EPM model above. Based on the understanding of the system gained from earlier studies at Glendhu, we have used a model comprising two DM models in parallel; a "double dispersion" model (DDM) (e.g. Stewart and Thomas, 2008). The two DMs describe short-transittime and long-transit-time flow components. The DDM model is simply formed by adding the two DM models:

$\mathrm{DDM}=b \mathrm{DM}_{1}+(1-b) \mathrm{DM}_{2}$

where $b$ is the fraction of the young component. The model has five parameters.

\section{Results}

\subsection{Tritium and other patterns}

Samples were collected from two tubes permanently inserted in the central wetland of GH5 (Fahey et al., 1998; Bowden et al., 2001). One was a piezometer tube drawing from $1 \mathrm{~m}$ depth near the mid-bog piezometer nest, the other from an aluminium tube drawing from $1.2 \mathrm{~m}$ depth near the lower piezometer nest. The latter tube (referred to as the N-tube) was used for neutron moisture probe measurements in the past. Not enough water could be extracted from the mid-bog tube for tritium analysis in 2005 . The results are given in Table 1 . The bog samples generally have higher tritium values than the stream samples (see below). CFC samples could not be collected from the bog sites as the entire amount of water extractable from the tubes was needed for tritium measurement.

Samples were collected from the small stream originating below the GH5 wetland. The stream gains in flow as it traverses the gradually steepening section away from the bog. The distance of each sample site from the head of the bog is given in Table 1. Tritium concentrations generally decrease away from the bog. CFC samples were collected at the stream sites. The CFC-11 and CFC- 12 concentrations in the stream near the wetland are considerably less than the concentrations expected for water in equilibrium with the atmosphere at the time of sampling, but are substantially above zero. Whether the streamwater retains its original CFC concentrations when recharged, or has been affected by chemical degradation in the bog is not clear, but the latter is likely. As 
Table 1. Analytical results for samples collected from the Glendhu Catchments.

\begin{tabular}{|c|c|c|c|c|c|c|c|c|c|}
\hline $\begin{array}{l}\text { Sample } \\
\text { site }\end{array}$ & Date & $\begin{array}{c}\text { Distance } \\
\mathrm{m}\end{array}$ & $\begin{array}{c}\text { Tritium } \\
\text { TU }\end{array}$ & $\begin{array}{c}\text { CFC-11 } \\
\text { pptv }\end{array}$ & $\begin{array}{c}\text { CFC-12 } \\
\text { pptv }\end{array}$ & $\begin{array}{c}\text { Temp } \\
{ }^{\circ} \mathrm{C}\end{array}$ & $\begin{array}{l}\mathrm{SiO}_{2} \\
\mathrm{mg} / \mathrm{L}\end{array}$ & $\begin{array}{c}\delta^{18} \mathrm{O} \\
\% \circ\end{array}$ & $\begin{array}{c}\delta^{2} \mathrm{H} \\
\% o\end{array}$ \\
\hline Midbog & $4 / 12 / 01$ & 75 & 2.97 & - & - & - & - & - & - \\
\hline N-tube & $4 / 12 / 01$ & 106 & 2.77 & - & - & - & - & - & - \\
\hline $20 \mathrm{~m} \mathrm{u} / \mathrm{s}$ GH5 & $4 / 12 / 01$ & 187 & 2.78 & 165.1 & 353.8 & - & - & - & - \\
\hline GH5 & $4 / 12 / 01$ & 207 & 2.78 & 139.4 & 335.0 & - & - & - & - \\
\hline $30 \mathrm{~m} \mathrm{~d} / \mathrm{s}$ GH5 & $4 / 12 / 01$ & 237 & 2.71 & 175.6 & 379.4 & - & - & - & - \\
\hline GH1 & $5 / 12 / 01$ & 1357 & 2.63 & 258.2 & 491.1 & - & - & - & - \\
\hline $\mathrm{GH} 2$ & $6 / 12 / 01$ & - & 2.69 & - & - & - & - & - & - \\
\hline Rainfall & 2000 & - & 2.55 & 257.6 & 539.7 & - & - & - & - \\
\hline N-tube & $22 / 02 / 05$ & 106 & 3.25 & - & - & - & 3.9 & -9.7 & - \\
\hline $15 \mathrm{~m} \mathrm{u} / \mathrm{s}$ GH5 & $22 / 02 / 05$ & 192 & 2.72 & 112.3 & 318.1 & 7.6 & 8.9 & -9.0 & - \\
\hline $20 \mathrm{~m} \mathrm{~d} / \mathrm{s}$ GH5 & $22 / 02 / 05$ & 227 & 2.61 & 208.3 & 494.9 & 8.3 & 10.7 & -8.9 & - \\
\hline $100 \mathrm{~m} \mathrm{~d} / \mathrm{s} \mathrm{GH} 5$ & $22 / 02 / 05$ & 307 & 2.45 & 228.4 & 522.5 & 8.3 & 11.2 & -9.0 & - \\
\hline GH1 & $21 / 02 / 05$ & 1307 & 2.29 & 245.4 & 540.9 & 10.0 & 14.4 & -9.0 & - \\
\hline $\mathrm{GH} 2$ & $22 / 02 / 05$ & - & 2.34 & - & - & - & 12.1 & -9.1 & - \\
\hline Rainfall & 2004 & - & 2.30 & 257.6 & 539.7 & - & - & - & - \\
\hline Midbog & $26 / 02 / 09$ & 75 & 2.59 & - & - & - & 6.6 & -8.98 & -60.4 \\
\hline N-tube & $26 / 02 / 09$ & 106 & 2.83 & - & - & - & $<0.05$ & -9.20 & -61.9 \\
\hline $5 \mathrm{~m} \mathrm{u} / \mathrm{s}$ GH5 & 26/02/09 & 202 & 2.90 & - & - & - & 3.7 & -9.12 & -62.4 \\
\hline $70 \mathrm{~m} \mathrm{~d} / \mathrm{s}$ GH5 & $26 / 02 / 09$ & 277 & 2.71 & - & - & - & 6.3 & -9.09 & -60.8 \\
\hline GH1 & $26 / 02 / 09$ & 1357 & 2.54 & - & - & - & 10.4 & -9.01 & -61.0 \\
\hline GH2 & 26/02/09 & - & 2.42 & - & - & - & 10.0 & -9.05 & -62.0 \\
\hline Waipori R & $26 / 02 / 09$ & - & 2.37 & - & - & - & 5.0 & -9.12 & -63.0 \\
\hline Rainfall & 2008 & - & 2.65 & - & - & - & - & - & - \\
\hline
\end{tabular}

the stream flows away from the wetland, the CFC concentrations tend to increase to approach equilibrium values with respect to the atmosphere.

The final samples were collected from the streams at the outlets of GH1 and GH2 catchments. Tritium concentrations were slightly higher than that of the rainfall average for 2001 on 6 December 2001, were close to the average for 2004 on 22 February 2005, and were lower than the average for 2008 on 26 February 2009. The CFC concentrations of GH1 were close to atmospheric levels in 2001 and 2005.

The tritium data are plotted in Fig. 3a. Water from depth in the wetland had tritium concentrations much higher than mean rainfall, suggesting that the water contains 'bomb' tritium (i.e. tritium originating from atmospheric nuclear weapons testing in the 1960s and 70s), and consequently part of the water has an age of 30 or more years. The stream draining the wetland (GH5) also has higher tritium than recent rainfall, and therefore is also likely to contain some of the old water. The peak tritium concentration may be gradually moving downstream, from the midbog sample in 2001, to the N-tube sample in 2005, and to the $5 \mathrm{~m} \mathrm{u}$ /s GH5 sample in 2009.

The CFC concentrations increase with distance away from the wetland (Fig. 3b), and quite quickly approach equilibrium with respect to the atmosphere. (The atmospheric CFC levels are shown in the figure.) This shows that the CFC concentrations are affected by interaction with the atmosphere as well as by input of young water, and therefore the GH1 and $\mathrm{GH} 2$ samples are not useful for estimating mean transit times of the water (Stewart et al., 2005a).

Silica concentrations also tend to increase away from the bog (Table 1, Fig. 3c). The $2009 \mathrm{~N}$-tube sample has zero silica, which appears to be due to chemical degradation due to the high organic content and acid condition at depth in the bog. The other bog samples are also relatively low in silica, while $\mathrm{GH} 1$ and $\mathrm{GH} 2$ have the highest silica concentrations. The $\delta^{18} \mathrm{O}$ values show very little variation (Table 1, Fig. $3 \mathrm{~d}$ ) except for the $2005 \mathrm{~N}$-tube sample, which may have retained its original $\delta^{18} \mathrm{O}$ value. The $2009 \delta^{2} \mathrm{H}$ values also show little variation; their values (Table 1) are very close to those observed by Bonell et al. (1990) in February-April 1988 for the "remarkably well-mixed shallow unconfined groundwater body" (i.e. -60.8 to $-62.4 \%$ ). Note that Glendhu lies close to the $-60 \%$ contour given by Stewart et al. (1983) for New Zealand precipitation.

\subsection{Estimation of mean transit times}

Using tritium to estimate mean transit times requires knowledge of the tritium input to the catchment. The tritium concentration in precipitation is based on measurements on monthly samples at Kaitoke (near Wellington), adjusted for latitude and altitude (Stewart and Taylor, 1981; Stewart and Morgenstern, 2001). Many years of monthly tritium 

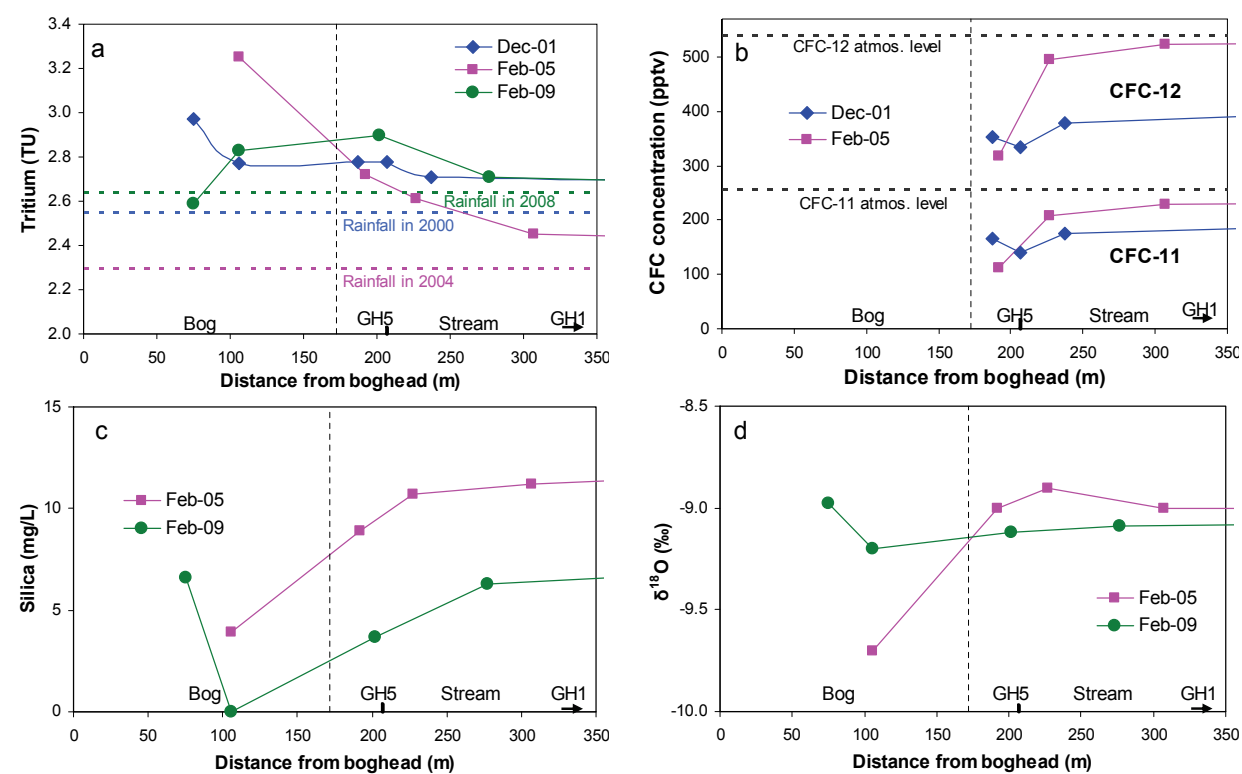

Fig. 3. Variation of tritium, CFC, silica and oxygen-18 concentrations in waters with distance from the head of the wetland in GH5 catchment. The dotted vertical lines show approximately where the stream begins.

Table 2. Best-fit parameters for simulation models (double dispersion model (DDM), dispersion model (DM), and exponential piston flow model (EPM). (The parameters of the young component of the DDM are $\tau_{m 1}=0.1$ year, $\mathrm{DP}_{1}=0.1$.)

\begin{tabular}{lcccccccccc}
\hline Site & \multicolumn{3}{c}{ Double dispersion model } & \multicolumn{3}{c}{ Dispersion model } & \multicolumn{3}{c}{ EPM } \\
\hline & $b$ & $\begin{array}{c}\tau_{m 2} \\
(\mathrm{yr})\end{array}$ & $\mathrm{DP}_{2}$ & $\mathrm{sd}$ & $\tau_{\mathrm{m}}$ & $\mathrm{DP}$ & $\mathrm{sd}$ & $\tau_{\mathrm{m}}$ & $f$ & $\mathrm{sd}$ \\
& & & & & $\mathrm{TU})$ & $(\mathrm{yr})$ & & $(\mathrm{TU})$ & $\begin{array}{c}(\mathrm{yr}) \\
(\%)\end{array}$ & $(\mathrm{TU})$ \\
GH1 & 0.84 & 25 & 0.04 & 0.04 & 1.0 & 2.3 & 0.05 & 0.5 & 100 & 0.11 \\
$\mathrm{GH} 2$ & 0.74 & 26 & 0.03 & 0.01 & 2.7 & 1.5 & 0.03 & 0.85 & 100 & 0.19 \\
Midbog & 0.77 & 34 & 0.01 & 0.00 & 3.9 & 3.1 & 0.00 & 41.5 & 19 & 0.06 \\
N-tube & 0.00 & 40 & 0.01 & 0.10 & 40 & 0.01 & 0.10 & 42 & 20 & 0.22 \\
GH5 & 0.69 & 39 & 0.01 & 0.11 & 0.6 & 10 & 0.12 & 0.1 & 100 & 0.23 \\
$70 \mathrm{~m} \mathrm{~d} / \mathrm{s} \mathrm{GH5}$ & 0.92 & 34 & 0.01 & 0.03 & 0.3 & 10 & 0.04 & 0.1 & 100 & 0.10 \\
\hline
\end{tabular}

$b$ is fraction of young component, $\tau_{\mathrm{m} 2}$ and $\mathrm{DP}_{2}$ are parameters of the old component in the DDM, sd is the goodness-of-fit expressed as the standard deviation of the simulation about the measurements, $\tau_{\mathrm{m}}$ and DP parameters of the DM, and $\tau_{\mathrm{m}}$ and $f$ parameters of the EPM.

measurements at Kaitoke and Invercargill Airport showed that while they had very similar variations, Invercargill Airport had tritium concentrations higher than Kaitoke by a factor of 1.1 because of its higher latitude. Adjusting for the $600 \mathrm{~m}$ altitude of the Glendhu Catchments increases this factor to 1.3. Other elevated locations for which this scale factor has been estimated are the Wairau River catchment (factor 1.35 , northeast South Island, mean altitude $1100 \mathrm{~m}$ ), the Waimakariri River (factor 1.2, east South Island, mean altitude $700 \mathrm{~m}$ ), and the Upper Motueka River (factor 1.2, north South Island, mean altitude $1000 \mathrm{~m}$ ) (Taylor et al., 1989, 1992; Stewart et al., 2005b). These all support a scale factor of about 1.3 for Glendhu.
We also need to adjust the precipitation for evapotranspiration (ET) as the water infiltrates the ground. ET preferentially removes summer precipitation during the recharge process. Precipitation is distributed uniformly throughout the year as demonstrated by records at Mahinerangi Dam located $20 \mathrm{~km}$ east of Glendhu. The 30-year mean summer and winter rainfalls at Mahinerangi were 490 and $482 \mathrm{~mm} / \mathrm{a}$, respectively for 1961-1990. The mean annual tritium concentrations in recharge $\left(\mathrm{C}_{\mathrm{in}}\right)$ for both $\mathrm{GH} 1$ and $\mathrm{GH} 2$ were corrected for ET as described in Stewart et al. (2007), using the equation

$C_{\mathrm{in}}=\sum_{i=1}^{12} C_{i} R_{i} / \sum_{i=1}^{12} R_{i}$ 
where $C_{i}$ and $R_{i}$ are the tritium concentrations in bulk rainfall and the recharge amounts for the ith month, respectively. The resulting tritium concentrations in recharge for catchment GH1 are shown in Fig. 4a. The corrections from use of Eq. (6) are very small.

The models described above are used to simulate the output tritium concentrations and find the model types and parameters that give the best fits to the data. The model fit is assessed using least squares regression (expressed as the standard deviation of the tritium simulation about the tritium measurements, i.e.

$\mathrm{sd}=\sqrt{\sum\left[\left(C_{s i}-C_{m i}\right)^{2}\right] / N}$

where $\mathrm{C}_{s i}, \mathrm{C}_{m i}$ are the simulated and measured tritium values, respectively, and $N$ is the number of measurements).

The best-fit parameters of the various models applied are given in Table 2. Results in the table show that the best DM and DDM fits are similar in quality to each other as shown by the standard deviation (sd), while the best EPM fits are much poorer in all cases. Figure $4 b$, c show the best-fit flow conceptualisations and transit time distributions with the DM and DDM for GH1. Both the DM and DDM have high peaks near zero age (the tops of which are not shown on Fig. $4 \mathrm{c}$ because of the scale) and long tails that extend to 50 years. With only two parameters the DM has a constrained shape, but it is apparent that by optimising the fit the model is trying to accommodate a lot of young water and some very old water. The DDM was used to try to delineate these two age components more clearly (i.e. the first DM accommodates the young water component, and the second DM the old water component). The transit time distribution of the DDM with its two peaks has approximately the same shape as the transit time distribution of the DM except for the middle portion (Fig. 4c). In contrast, the EPM transit time distribution cannot be changed enough to accommodate the measurements well (Table 2), because $f$ (the ratio of the exponential to the total volume) cannot be greater than $100 \%$. The double EPM (DEPM) likewise is not as satisfactory as the DDM.

\subsubsection{GH1 and GH2 catchments}

The tritium measurements (and their errors) and the simulations for GH1 and GH2 are plotted in Fig. 5a and b with an expanded tritium scale. Variation of the goodness-of-fit indicator (sd) with the mean transit time $\left(\tau_{\mathrm{m}}\right)$ for the DM is shown in Fig. 5c, and that for the DDM with the mean transit time of the old water component $\left(\tau_{\mathrm{m} 2}\right)$ in Fig. $5 \mathrm{~d}$. The bestfitting simulations agree with the data to within the measurement error $( \pm 0.05 \mathrm{TU})$.

With the DM, the best-fitting mean transit times for GH1 and $\mathrm{GH} 2$ are $1.0 \pm 0.1$ and $2.7 \pm 0.1$ years, respectively, where the uncertainties are based on the tritium measurement error. (The uncertainties are calculated by combining the measurement errors of the three points (using the expression $(1 / \mathrm{N}) \sqrt{ } \sum \sigma_{i}^{2}$, where $\sigma_{i}$ are the measurement errors and $\mathrm{N}$ the
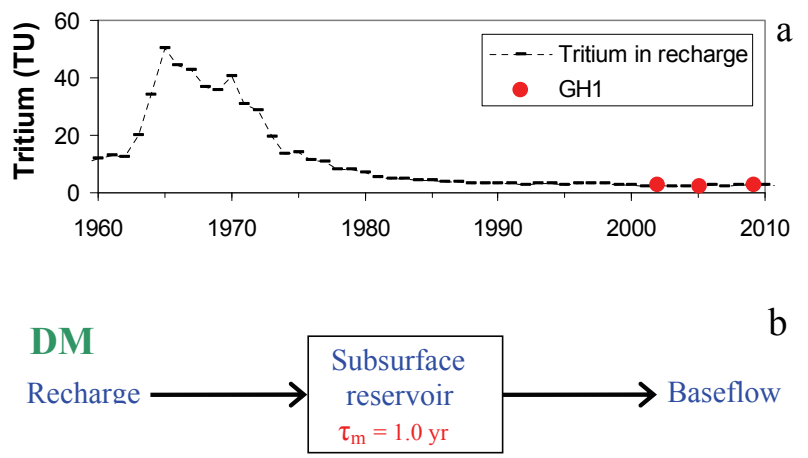

b
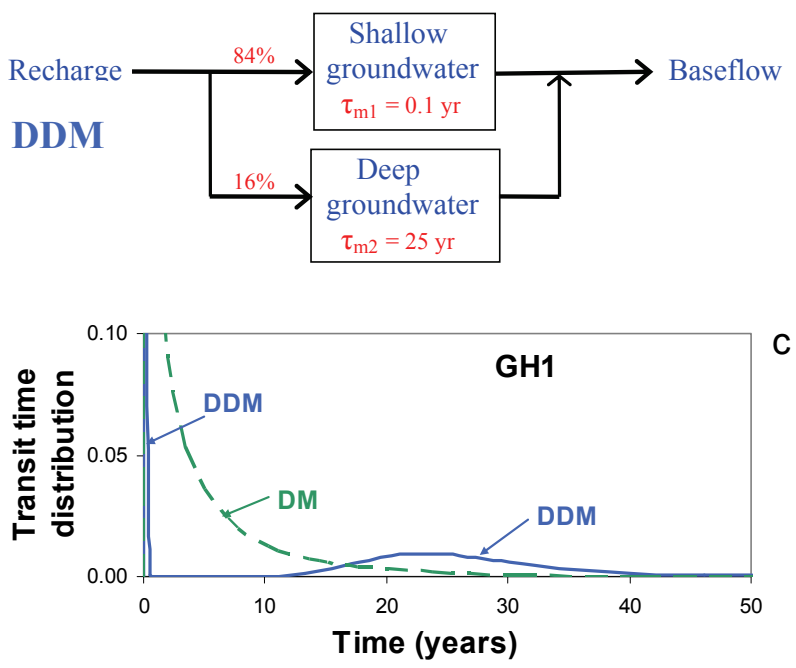

Fig. 4. (a) Tritium concentration in recharge for GH1. (b) Conceptualisation of baseflow using the DM and DDM models at GH1. (c) Best-fit transit time distributions with the DM and DDM models for GH1.

number of measurements) and fitting curves to the high and low values of the measurements.) Fig. 5c shows that the minimum values in the sd are broad and unambiguous. However the transit time distributions have rather distorted shapes (i.e. high peaks near zero and long tails, see Fig. 4c), because of their high values of the dispersion parameter. Maloszewski and Zuber (1982) showed that the maximum DP expected for an unconfined aquifer would be about 2 , and the same reasoning suggests that the maximum for a catchment should be about 1.4 (assuming a roughly circular shape). Hence, the high DP values suggest that two water components are present, and the DDM is used to resolve the young and old components in the streamflow.

The DDM has five parameters, two each describing the components and one their relative proportions. The young component is assumed to have a one month mean transit time and dispersion parameter of 0.1 (the fit is insensitive to the latter). The 1-month mean transit time is considered approximate because average annual tritium input data has 

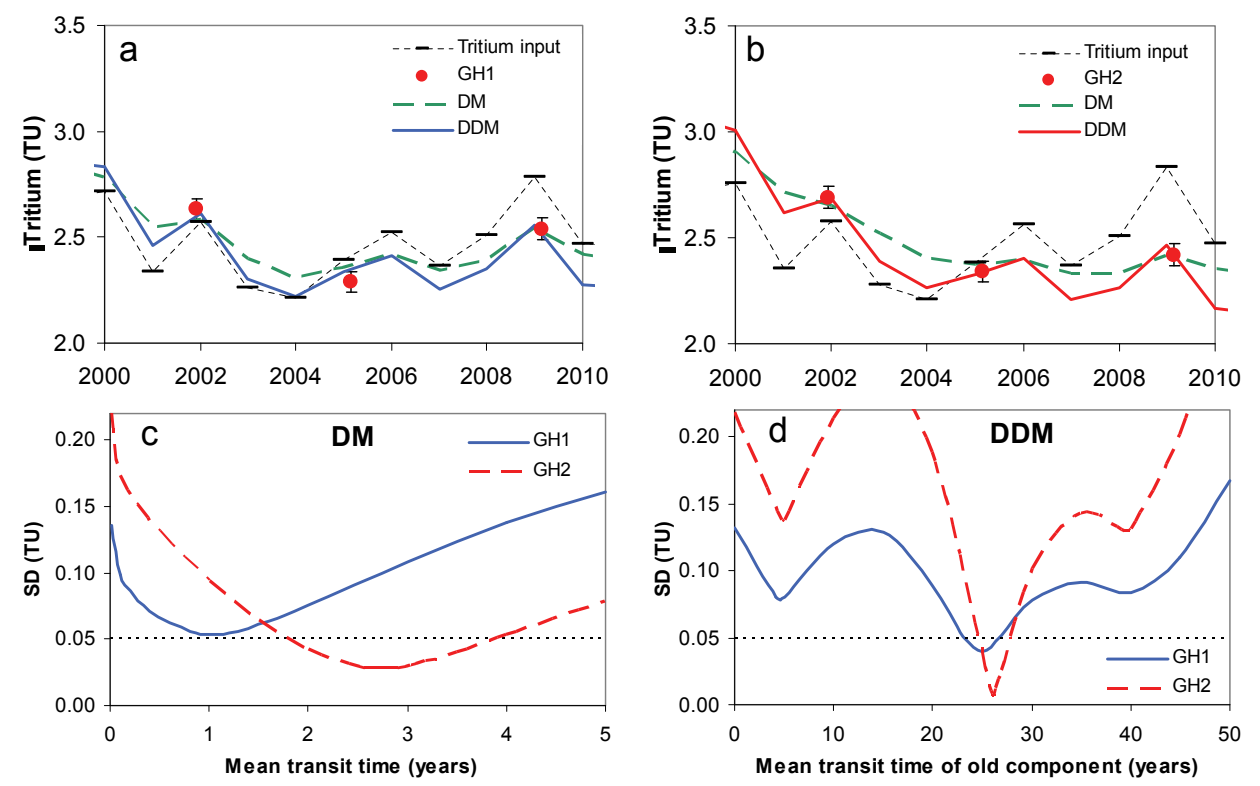

Fig. 5. Tritium measurements and simulations for stream sites GH1 and GH2. Variation of the quality of fit (sd) with mean transit time for the DM, and mean transit time of the old component for the DDM. The dotted line shows the measurement error (0.05 TU).

been used. The best-fitting mean transit times for the old component are $25 \pm 2$ years for $\mathrm{GH} 1$ and $26 \pm 1$ years for $\mathrm{GH} 2$ (Fig. 5d), although there are subsidiary minima at 4 years and 40 years. These subsidiary minima are rejected because they give relatively poor fits for all of the sites (including GH1 where they give sd $\sim 0.08 \mathrm{TU}$, compared with the best-fit sd of $0.04 \mathrm{TU}$ at 25 years). The young fractions $(0.84 \pm 0.01$ for GH1 and $0.74 \pm 0.01$ for GH2) indicate that the majority of the water in the streams is young. This young water is expected to be derived from the shallow groundwater connecting the near-surface layers of the wetlands and the surrounding hillslopes with the stream (Bonell et al., 1990; Fahey et al., 1998; Bowden et al., 2001). But there is also a substantial fraction of old water in the streamflow in both catchments.

\subsubsection{GH5 catchment and stream}

Some insight into the nature of the deep component can be gained from looking at the results for GH5 and the stream deriving from it (Fig. 6a to d). Both DM and DDM results are plotted, but the descriptions below refer mainly to the DDM results. The best-fit DM parameter sets at three of the sites have young overall mean transit times and high DP values - two have DP $\sim 10$ which was set as an arbitrary limit (otherwise the values would have been higher). The high DP values indicate a wide distribution of ages, with much very young water and some very old water. The $\mathrm{N}$-tube site has only the old component. Only two tritium samples were collected from the midbog tube. Application of the DDM model (Fig. 6a, Table 2) gives a two-component mixture contain- ing $23 \%$ old water ( $\tau_{\mathrm{m} 2} \sim 34$ years), with the remainder being young water $\left(\tau_{\mathrm{m} 1} \sim 1\right.$ month). The $\mathrm{N}$-tube samples can only be fitted with a sharply-peaked old component $\left(\tau_{\mathrm{m} 2}=40\right.$ years), with no young component present, i.e. the DDM is the same as the DM result. The "GH5 stream" samples (the averages of the $20 \mathrm{~m} \mathrm{u} / \mathrm{s}$ GH5 and GH5 samples from 4 December 2001, $15 \mathrm{~m} \mathrm{u} / \mathrm{s} \mathrm{GH} 5$ and $20 \mathrm{~m} \mathrm{~d} / \mathrm{s} \mathrm{GH} 5$ samples on 22 February 2005, and $5 \mathrm{~m} \mathrm{u} / \mathrm{s}$ GH5 sample on 26 February 2009, see Table 1) are matched by $31 \%$ of the same old component $\left(\tau_{\mathrm{m} 2}=40\right.$ years, $\left.\mathrm{DP}_{2}=0.01\right)$, and $69 \%$ of the young component. The "70 m d/s GH5" stream samples $(30 \mathrm{~m} \mathrm{~d} / \mathrm{s}$ on 4 December 2001, $100 \mathrm{md} / \mathrm{s}$ on 22 February 2005 and $70 \mathrm{~m}$ $\mathrm{d} / \mathrm{s}$ on 26 February 2009) have $8 \%$ old component $\left(\tau_{\mathrm{m} 2}=40\right.$ years, $\mathrm{DP}_{2}=0.01$ ) and $92 \%$ young component. With increasing distance downstream, the flow in the stream increases and the proportion of young water rises. Old water drains from the bog, but it is probably sourced ultimately from deep storage (groundwater), which rises through or around the bog.

\section{Discussion}

\subsection{Choice of transit time distribution model and equifinality}

It is apparent that streamflow can be supplied from a variety of sources within a catchment (or even from outside it by subsurface paths), and each source will have its own particular flowpaths and transit times depending on its nature. McDonnell et al. (2010) have pointed out that the resulting distribution of transit times in streams is largely unknown 

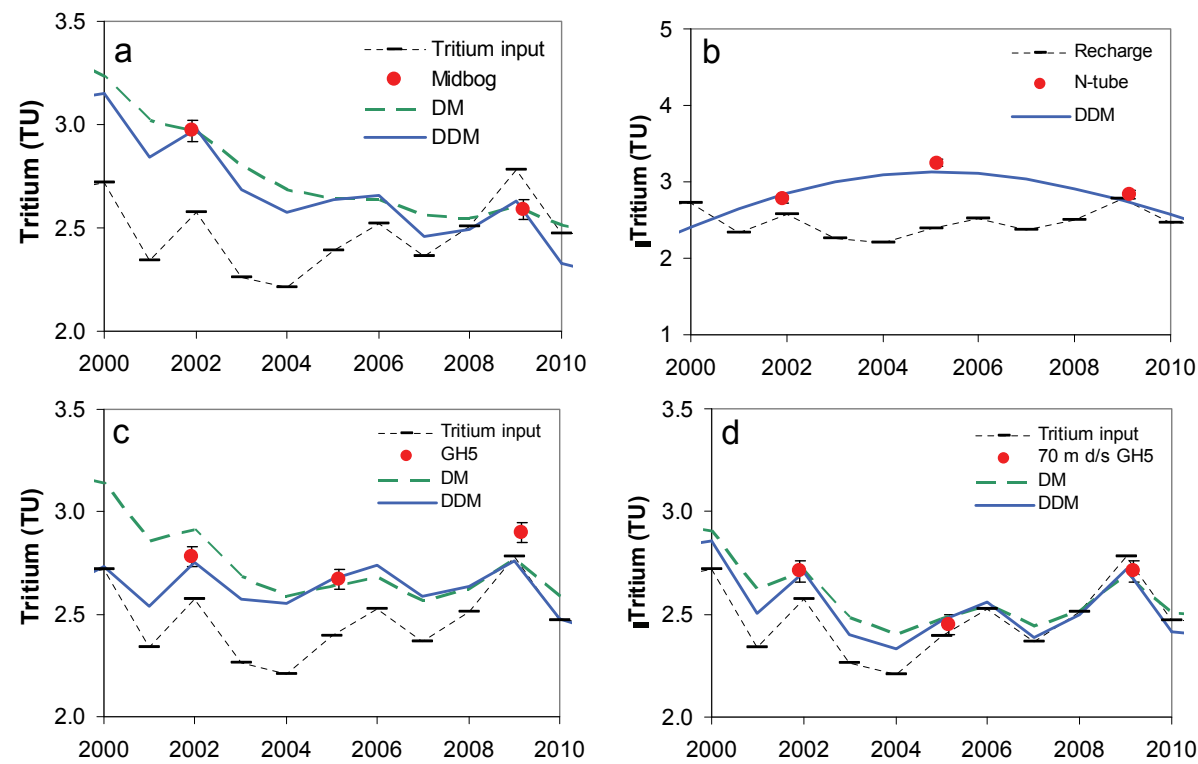

Fig. 6. Tritium measurements and simulations for midbog, N-tube, GH5 and $70 \mathrm{~m} \mathrm{~d} / \mathrm{s}$ GH5 sites.

at present. However, there are strong indications that the distribution can be very wide with substantial amounts of both very young water and "surprisingly" old water (Kirchner et al., 2000). They showed that chloride results on Plynlimon streams implied very wide transit time distributions that could be described by the gamma flow model, but not by the exponential or dispersion models. This result has been confirmed more generally by measurements on many other streams (Godsey et al., 2010). The presence of substantial amounts of old water in many streams and rivers has also been established by Stewart et al. (2010) from a survey of the literature on tritium measurements in streams.

At Glendhu, there are indications of very old water in the stream from the presence of bomb-peak tritium (i.e. by stream tritium concentrations being greater than current recharge tritium levels), while the bulk of the water appears to be quite young. The dispersion model (DM) gives good fits to the data, but requires values of the parameter DP that are greater than the maximum reasonably expected for a catchment (about 1.4). Consequently, a two-component transit time distribution is considered the most suitable for interpreting the results. The two components have transit time distributions represented by dispersion models, and the combination of the two in parallel is the "double dispersion" model (DDM). The DDM produces the best simulations to the data at all of the sites. The exponential piston flow model (EPM) gives relatively poor fits to the data, because the distribution cannot be 'stretched' enough since $f$ (the ratio of the exponential to the total volume) cannot be greater than $100 \%$. (However the gamma model, of which the exponential model is a special case, would very likely give good fits to the data, Kirchner et al., 2000.)
Regarding equifinality, it is probable that a number of different models and parameterisations could give good fits to the data, especially as there are only three measurements at each site. (e.g. It would be interesting to try a model with three water components, such as one with three DMs in parallel.) But these could multiply the number of parameters. Given the need to limit parameters, the DDM is considered the best choice. Note that even single measurements of tritium can in principle give unambiguous estimates of age when the tritium concentration in the stream is low compared with the current rainfall level. The present measurements are 3-4 years apart in time, and therefore are useful for estimating longer transit times. More measurements at short time intervals would be needed to investigate the young water component of the DDM in more detail. More measurements in the future could also help to refine the transit time distribution.

\subsection{Flow components - relation to master recession curve}

Previous hydrometric studies at Glendhu revealed a marked change of slope in the recession hydrographs for GH1 and GH2 (Pearce et al., 1984), suggesting that there is a change in the dominant runoff generating processes at that point. Deuterium and chloride measurements in streamflow (Bonell et al., 1990) showed that the first part of the recession (quickflow) contained pre-event water (with very uniform deuterium and chloride concentrations), plus new water from the current event if quickflow yields exceeded $10 \mathrm{~mm}$. The second part of the recession (baseflow) contained only the very uniform pre-event water. These observations were explained 
by runoff being supplied by groundwater bodies connecting regolith on the hillsides with the stream. When sufficient rain has fallen to exceed near-surface storage in the wetlands and lower slopes, runoff is augmented by event water via saturation overland flow. When rainfall is insufficient, quickflow contains only pre-event water. In the former case, pre-event water responds more rapidly to rainfall than event water.

This study has probed the transit times of water contributing to the second part of the recession. Tritium measurements have indicated that surprisingly old water is present in the streams and contributes significantly to baseflow and therefore probably to quickflow, although the remainder of the water is quite young (with transit times of a few months). The age of the old water component is revealed by the presence of tritium originating from the bomb-peak in NZ rainfall in the late 1960s and early 1970s. A mean transit time of 2526 years is obtained for catchments GH1 and GH2. At GH1, annual baseflow amounts to about $520 \mathrm{~mm} / \mathrm{a}$ (i.e. $70 \%$ of annual runoff). The old component runoff is therefore $83 \mathrm{~mm} / \mathrm{a}$ (16\% of baseflow). For GH2, the old component runoff is about $88 \mathrm{~mm} / \mathrm{a}$ annually ( $26 \%$ of baseflow). The closeness of these figures shows that roughly equal amounts of old water are supplied to the streams in the two catchments per catchment area.

The GH1 and GH2 samples were all collected during moderate baseflow conditions in summer. Flows were between $480-600 \mathrm{~mm} / \mathrm{a}(\mathrm{GH} 1)$ and $380-530 \mathrm{~mm} / \mathrm{a}(\mathrm{GH} 2)$. It is expected that the fraction of the young component (b) would tend to be greater at higher baseflow giving the streamwater a younger overall mean transit time $\left(\tau_{\mathrm{m}}\right)$, according to the equation

$\tau_{m}=b \tau_{\mathrm{m} 1}+(1-b) \tau_{\mathrm{m} 2}$

Thus $\tau_{\mathrm{m}}$ may vary approximately inversely with streamflow. Future measurements at a wider variety of streamflows would be needed to establish this.

Old water is also observed within the GH5 wetland (Midbog, N-tube and GH5 stream sampling sites), and the N-tube site has $100 \%$ old water. Such water is held at depth within the peat and only slowly released. It appears to be associated with outflow of a deep aquifer into the bog peat. There may also be gradual movement of bomb-tritium water downstream along the wetland as younger water penetrates from the head end of the bog (Fig. 3a). The midbog and GH5 sites have 23 and $31 \%$ of the deep-sourced old water, respectively. Young water flowing through the near surface of the wetland and slopes contributes the remainder.

The $70 \mathrm{~m}$ downstream GH5 site has the smallest amount of old water (8\%). Enough young water has entered the stream at this point to strongly dilute the old water from the GH5 wetland (streamflow is much larger here than in the stream near GH5). And the young water itself must contain an even smaller proportion of old water. Lower down in the GH1 catchment (at GH1 weir) the larger streamflow nevertheless contains a higher proportion of old water (16\%) suggesting that more deep groundwater is supplied to the stream lower down in the catchment.

\subsection{Source of old component}

What do these long transit times mean in regard to water flows in the catchment? The importance of interflow in producing stormflow has been demonstrated by earlier workers (Miller, 1994; Bowden et al., 2001). Bowden et al. (2001) showed that lateral flow in the thin Organic and A Horizon layers was substantial and probably often emerged as flow over the wetland surface in high quickflow events, contributing to the new water inputs to the streams. They identified slow drainage from deep loess horizons (layers B and C) as the source of the extended baseflow in the catchments. Such drainage from the $1.5 \mathrm{~m}$ loess horizons and weathered bedrock colluvium mantling the slopes would be connected by a shallow groundwater system to the stream. While this is a likely source of young water in the baseflow, it is highly improbable that the loess could introduce the mean delay of 25-26 years identified by tritium in the old water fraction. Water flowing over bedrock would be expected to travel quite rapidly hence the long delay would have to derive from drainage from the unsaturated loess and bedrock colluvium. It is much more probable that the old water results from slow flow through the bedrock itself, as schematically illustrated in Fig. 7a and b. Wetlands in valley bottoms may also help to trap old water at depth by slowing the egress of water from the deep groundwater systems.

Consideration of the storage required to produce such old water supports the presence of bedrock aquifers. A water store of $2.2 \mathrm{~m}$ thickness is required to supply $85 \mathrm{~mm} / \mathrm{a}$ for 25.5 years (catchments GH1 and GH2). Assuming total porosity of 0.1 , this implies an aquifer thickness of $22 \mathrm{~m}$ over the catchments - far too much to be accommodated in the loess and colluvium.

\subsection{Environmental change and catchment storage}

Afforestation of GH2 has reduced the runoff substantially (by $260 \mathrm{~mm} / \mathrm{a}$ after 7 years) mainly by increased interception loss (Fahey and Jackson, 1997). McLean (2001) and Fahey (2010, unpublished) sought to determine whether the rate of recession has changed in response to afforestation of $\mathrm{GH} 2$, but found no significant changes in slope. However, the fraction of old water in baseflow at GH2 (26\%) is higher than that at GH1 (16\%), leading to roughly equal amounts of runoff of old water in the two catchments. This may be showing that runoff has been reduced from the shallow regolith aquifer of $\mathrm{GH} 2$, but not yet from the deep bedrock aquifer. 

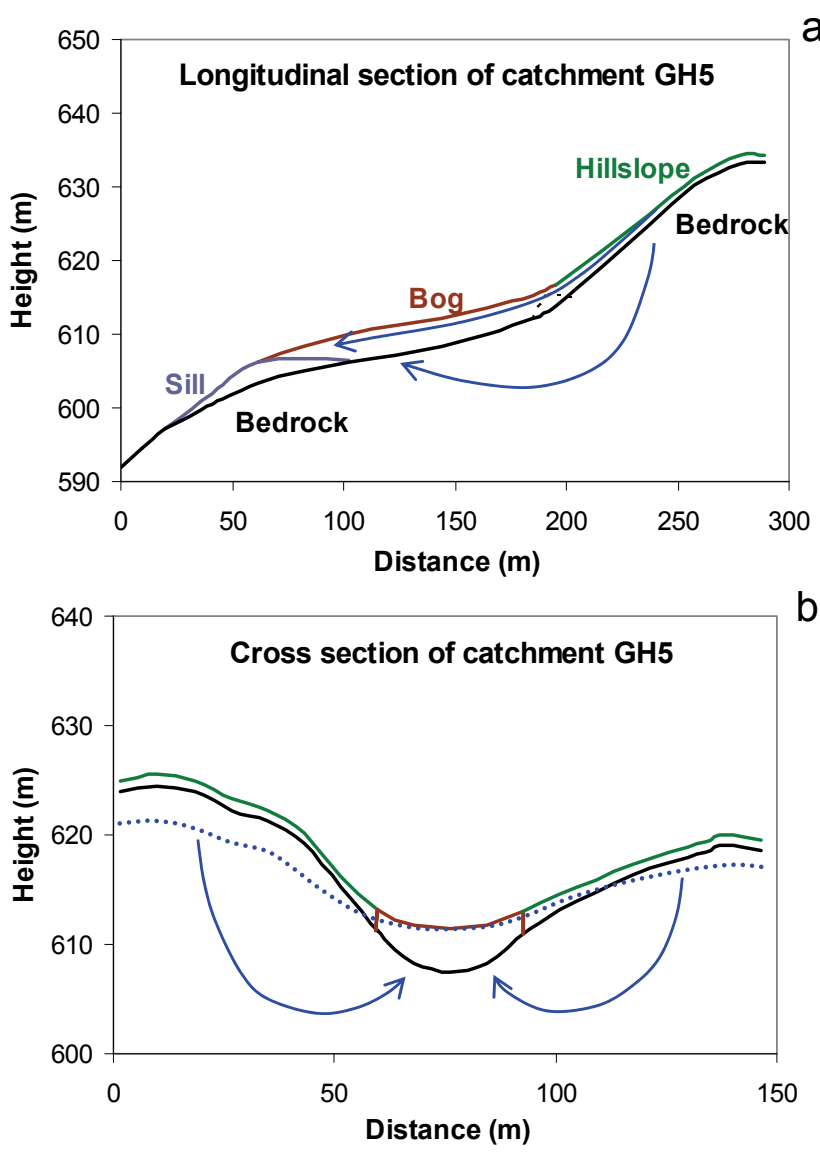

Fig. 7. Longitudinal and cross sections for catchment GH5.

Catchment scale storage has become of increasing interest because such storage affects how rapidly the stream responds to environmental change such as land use or climate change (Soulsby et al., 2009). Catchments with low storage will respond more rapidly than catchments with greater storage. The transit time distribution in runoff affects how long soluble contaminants are retained in a catchment. The presence of long transit time water in the Glendhu catchments means that soluble contaminants will be retained in the catchment and stream concentration will be elevated for many years following a contamination event. Concentrations will initially fall because of the young water present, but then the decline will slow as old water feeds into the stream.

\section{Conclusions}

The east Otago uplands of New Zealand's South Island have been studied because of the environmental consequences of converting native tussock grasslands to other land covers, notably forestry and pasture for stock grazing. Tritium measurements have been used to estimate the transit times of water contributing to baseflow based on the double dispersion flow model. The tritium measurements showed that minor but substantial amounts of old water contribute to the GH1 and GH2 streams, and the stream draining the GH5 wetland. The remainder of the water is young. It appears that baseflow derives from two sources, shallow aquifers connecting regolith on the hillsides with the stream and including shallow layers of the headwater wetlands, and deep aquifers within bedrock connecting with the stream and deep layers of the wetland. Although the latter only provides $16 \%$ (GH1) and $26 \%$ (GH2) of baseflow, it constitutes by far the larger of the two water stores. The old water apparently reaches the streams mainly from low down in GH1 and GH2 catchments, but also via wetlands like GH5. About $85 \mathrm{~mm} / \mathrm{a}$ of runoff is contributed annually from the deep aquifers in both catchments - it appears that afforestation has not yet affected the flow from deep storage in catchment GH2. This study has reinforced the importance of bedrock flow in contributing to runoff in a crystalline metamorphic setting.

Acknowledgements. We thank the staff of Rayonier New Zealand Ltd, Invercargill, for giving us access to Glendhu Forest. This research was partially funded by the New Zealand Foundation for Research, Science, and Technology, the Korean Research Foundation (KRF 2001-013-G00012), the Hellaby Indigenous Grasslands Research Trust, and the Dunedin City Council.

Edited by: L. Pfister

\section{References}

Bonell, M., Pearce, A. J., and Stewart, M. K.: The identification of runoff-production mechanisms using environmental isotopes in a tussock grassland catchment, Eastern Otago, New Zealand, Hydrol. Process., 4, 15-34, 1990.

Bowden, W. B., Fahey, B. D., Ekanayake, J., and Murray, D. L.: Hillslope and wetland hydrodynamics in a tussock grassland, Southland, New Zealand, Hydrol. Process., 15, 1707-1730, 2001.

Busenberg, W., and Plummer, L.N.: Use of chlorofluorocarbons $\left(\mathrm{CCl}_{3} \mathrm{~F}\right.$ and $\left.\mathrm{CCl}_{2} \mathrm{~F}_{2}\right)$ as hydrologic tracer and age-dating tools: the alluvium and terrace system of Central Oklahoma, Water Resour. Res., 28, 2257-2283, 1992.

Campbell, D. I., and Murray, D. L.: Water balance of snow tussock grassland in New Zealand. J. Hydrol., 118, 229-245, 1990.

Fahey, B. D., Bowden, W. B., Smith, J., and Murray, D. L.: Hillslope-wetland hydrological linkages in the headwaters of a tussock grassland catchment at Glendhu, South Island, New Zealand, in: Hydrology, Water Resources, and Ecology of Headwaters. Proceedings of the HeadWater '98 Conference, Meran/Merano, Italy, IAHS Publication No. 248, 157-164, 1998.

Fahey, B. D. and Jackson, R. J.: Hydrological impacts of converting native forest and grasslands to pine plantations, South Island, New Zealand, Agric. Forest Meteorol., 84, 69-82, 1997.

Godsey, S. E., Aas, W., Clair, T. A., de Wit, H. A., Fernandez, I. J., Kahl, J. S., Malcolm, I. A., Neal, C., Neal, M., Nelson, S. J., Norton, S. A., Palucis, M. C., Skjelvale, B. L., Soulsby, C., 
Tetzlaff, D., Kirchner, J. W.: Generality of fractal 1/f scaling in catchment tracer time series, and its implications for catchment travel time distributions, Hydrol. Process., 24, 1660-1671, 2010.

Hewlett, J. D. and Hibbert, A. R.: Factors affecting the response of small watersheds to precipitation in humid areas. In Sopper, W.E., Lull, H.W. (Eds.), Forest Hydrology, Oxford, Pergamon, 275-290, 1967.

Hulston, J. R., Taylor, C. B., Lyon, G. L., Stewart, M. K., and Cox, M. A.: Environmental isotopes in New Zealand hydrology. Part 2. Standards, measurement techniques and reporting of measurements for oxygen 18 , deuterium and tritium in water, N. Z. J. Sci., 24, 313-322, 1981.

Kirchner, J. W., Feng, X., and Neal, C.: Fractal stream chemistry and its implications for contaminant transport in catchments, Nature, 403, 524-527, 2000.

Maloszewski, P. and Zuber, A.: Determining the turnover time of groundwater systems with the aid of environmental tracers, 1. Models and their applicability. J. Hydrol., 57, 207-331, 1982.

McDonnell, J. J., McGuire, K., Aggarwal, P., Beven, K., Biondi, D., Destouni, G., Dunn, S., James, A., Kirchner, J., Kraft, P., Lyon, S., Maloszewski, P., Newman, B., Pfister, L., Rinaldo, A., Rodhe, A., Sayama, T., Seibert, J., Solomon, K., Soulsby, C., Stewart, M., Tetzlaff, D., Tobin, C., Troch, P., Weiler, M., Western, A., Wörman, A., and Wrede, S.: How old is streamwater? Open questions in catchment transit time conceptualization, modelling and analysis, Hydrol. Process. 24, 1745-1754, 2010.

McLean, S.: Baseflow response to vegetation change, Glendhu State Forest, Otago, New Zealand. MSc Thesis, University of Otago, Dunedin, New Zealand, 2001.

McGlynn, B. L., McDonnell, J. J., Stewart, M. K., and Seibert, J.: On the relationships between catchment scale and streamwater mean residence time, Scientific Briefing, Hydrol. Proc., 17, 175181, 2003

Miller, B. J.: Soil water regimes of the Glendhu Experimental Catchments, BSc Honours thesis, University of Otago, Dunedin, New Zealand, p. 81, 1994.

Morgenstern, U. and Taylor, C. B.: Ultra low-level tritium measurement using electrolytic enrichment and LSC, Isot. Environ. Healt. S, 45, 96-117, 2009.

Pearce, A. J., Rowe, L. K., and O'Loughlin, C. L.: Hydrology of mid-altitude tussock grasslands, Upper Waipori catchment, Otago II. Water balance, flow duration, and storm runoff, J. Hydrol. (N. Z.), 23, 45-59, 1984.

Plummer, L. N. and Busenberg, E.: Chlorofluorocarbons. Chapter 15 in Environmental Tracers in: Subsurface Hydrology, edited by: Cook, P. and Herczeg, A. L., Kluwer Academic Publishers, 441-478, 1999.

Soulsby, C., Tetzlaff, D., and Hrachowitz, M.: Tracers and transit times: windows for viewing catchment scale storage? Hydrol. Process. 23, 3503-3507, 2009.
Stewart, M. K., Cameron, S. C., Hong, T. Y.-S., Daughney, C. J., Tait, T., and Thomas, J. T.: Investigation of groundwater in the Upper Motueka River Catchment, GNS Science Report 2003/32, p. 47, 2005 b.

Stewart, M. K., Cox, M. A., James, M. R., and Lyon, G. L.: Deuterium in New Zealand rivers and streams, INS Rept. No. INSR320, p. 32, 1983.

Stewart, M. K., Fahey, B. D., and Davie, T. J. A.: New light on streamwater sources in the Glendhu Experimental Catchments, East Otago, New Zealand. N.Z.H.S., I.A.H., N.Z.S.S.S. Conf. "Where Waters Meet", Auckland, N. Z., Nov., 2005a.

Stewart, M. K., Mehlhorn, J., and Elliott, S.: Hydrometric and natural tracer $\left({ }^{18} \mathrm{O}\right.$, silica, ${ }^{3} \mathrm{H}$ and $\left.\mathrm{SF}_{6}\right)$ evidence for a dominant groundwater contribution to Pukemanga Stream, New Zealand, Hydrol. Process., 21, 3340-3356, 2007.

Stewart, M. K. and Morgenstern, U.: Age and source of groundwater from isotope tracers, in: Groundwaters of New Zealand, edited by: Rosen, M. R. and White, P. A., N. Z. H. S., Wellington, New Zealand, 161-183, 2001.

Stewart, M. K., Morgenstern, U., and McDonnell, J. J.: Truncation of stream residence time: How the use of stable isotopes has skewed our concept of streamwater age and origin, Hydrol. Process., 24, 1646-1659, 2010.

Stewart, M. K. and Taylor, C. B.: Environmental isotopes in New Zealand hydrology. Part 1. Introduction: The role of oxygen18, deuterium and tritium in hydrology, N. Z. J. Sci., 24, 295-311, 1981.

Stewart, M. K. and Thomas, J. T.: A conceptual model of flow to the Waikoropupu Springs, NW Nelson, New Zealand, based on hydrometric and tracer $\left({ }^{18} \mathrm{O}, \mathrm{Cl},{ }^{2} \mathrm{H}\right.$ and CFC) evidence, Hydrol. Earth Syst. Sci., 12, 1-19, doi:10.5194/hess-12-1-2008, 2008.

Taylor, C. B.: The relationship between electrolytic deuterium and tritium separation factors, and attainment of improved accuracy in radiometric low-level tritium measurement, J. Appl. Rad. Isotopes, 45, 683-692, 1994.

Taylor, C. B., Brown, L. J., Cunliffe, J. J., and Davidson, P. W. Environmental isotope and ${ }^{18} \mathrm{O}$ applied in a hydrological study of the Wairau Plain and its contributing mountain catchments, Marlborough, New Zealand. J. Hydrol., 138, 269-319, 1992.

Taylor, C. B., Wilson, D. D., Brown, L. J., Stewart, M. K., Burdon, R. J., and Brailsford, G. W.: Sources and flow of North Canterbury Plains groundwater, New Zealand. J. Hydrol.,106, 311-340, 1989.

Van der Raaij, R.: Age dating of New Zealand groundwaters using sulphur hexafluoride, M. Sc., School of Earth Sciences, Victoria University of Wellington, New Zealand, 2003. 